\title{
The "Rede Brasil de Bibliotecas Comunitárias": a space for sharing information and building new knowledge
}

\section{Elisa Campos Machado}

Universidade Federal do Estado do Rio de Janeiro. Escola de Biblioteconomia

\section{Geraldo Moreira Prado}

Instituto Brasileiro de Informação em Ciência e Tecnologia. Graduate Program in Information Science

\author{
Abraão Antunes da Silva \\ Universidade de São Paulo. Escola de Comunicação e Artes. Librarianship Student
}

\section{Jailton Lira}

Universidade Federal do Estado do Rio de Janeiro. Projeto de Extensão Universitária Rede Brasileira de Bibliotecas Comunitárias - Collaborating researcher

\section{Kleber Tadashi}

Centro Educacional Unificado Capão Redondo

\begin{abstract}
This is a report on the experience of creating the Rede Brasil de Bibliotecas Comunitárias (RBBC), an online social network that aims to bring together and share information regarding practices employed in setting up local library collections and making them available to the public; discussing the principles that govern the autonomous management of these spaces; establishing ties and creating exchanges between the different agents and spheres involved in this process; and encouraging society's participation in the construction of public policy for Brazilian libraries. The work presents the theoretical references that make up the foundation of the proposal, the methodology employed and analyzes the data obtained during the first ten months of the network's existence.
\end{abstract}

Keywords: Social networks; Community Libraries; Public Libraries; Public Policies for libraries 


\section{INTRODUCTION}

The Rede Brasil de Bibliotecas Comunitárias (RBBC) (The Brazil Network of Community Libraries) was created after identifying the lack of formal spaces to debate the reality of Community Libraries in Brazil, a fact that became clear during the II Seminário Internacional de Bibliotecas Públicas e Comunitárias, which took place in November 2009 in the city of São Paulo and was organized by the Secretaria de Cultura of the government of São Paulo State.

Based on this realization, a group of participants in the seminar, made up of students of Librarianship and Information Science, as well as librarians, researchers in these fields and local leaders in charge of community libraries, decided to create a social network on the internet that would have the following aims: to bring together and share information regarding the practices employed in setting up and providing access to local collections, especially to members of disadvantaged groups; discuss and reflect upon the principles that govern the autonomous management of these spaces; establish ties and promote exchanges between the different agents and spheres involved in this process; and encourage society's participation in the construction of public policy for Brazilian libraries.

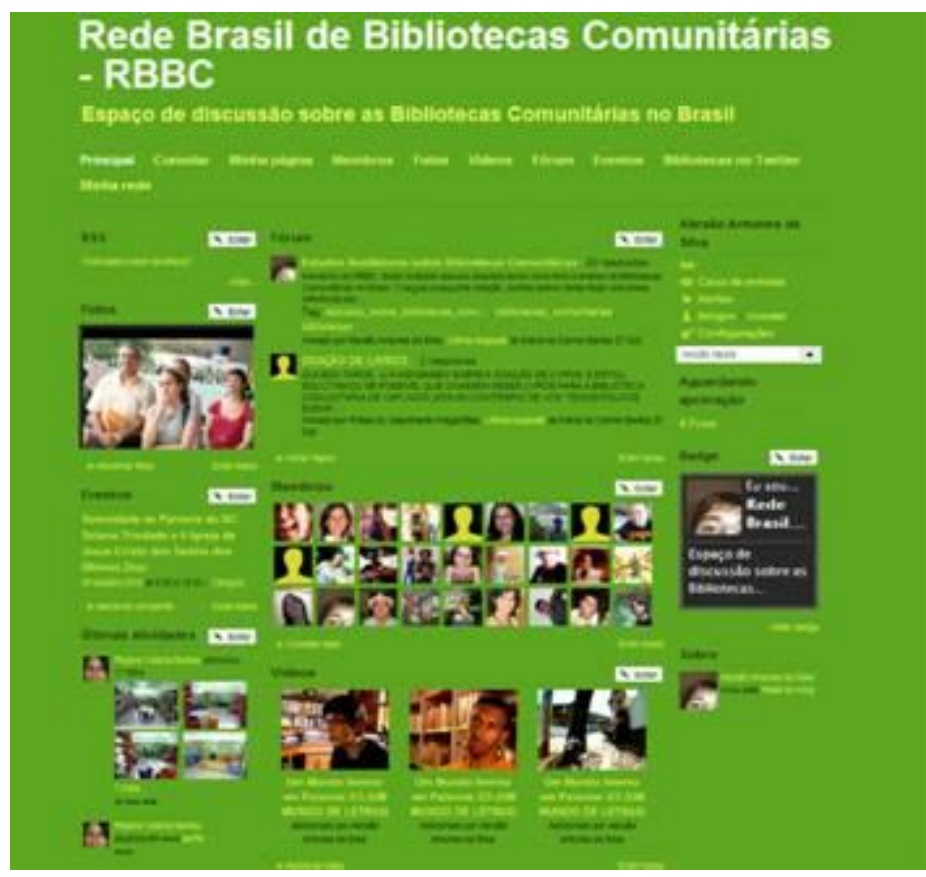

Figure 1: RBBC Homepage

Source: http://rbbconexoes.ning.com [acessed on 30/10/2010]

Community libraries in Brazil exist as spontaneous practices, idealized and implemented by individual or collective agents - average citizens, with or without formal training, with or without institutional support. They are generally set up in peripheral locations as a result of the difficult access to cultural goods in these locations and to the utter absence of actions on the part of the State. These new reading spaces, for the most part, have been created by people that are in no way connected to the fields of Librarianship or Information Science. Their aim is to bring 
together a collection to provide access to books and reading material, especially for children and young members of a given area.

The process of socio-cultural exclusion in Brazil continues to be a reality to populations in peripheral zones, either in the large urban centers like Rio de Janeiro and São Paulo, or in smaller communities or rural zones, such as the town of São José do Paiaia, in the semi-arid region of Bahia.

Data from the $1^{\text {st }}$ Census of Public Municipal Libraries in 2010, created by the Ministério da Cultura and the Fundação Getúlio Vargas, clearly show that this is indeed the case: $8 \%$ of Brazilian municipalities in the present day do not have a single public library to provide for their inhabitants; another $12 \%$ are currently in the process of implementing such a service. Graph 1, below, shows the regional disparities that exist in regard to the presence of these public cultural spaces.

MUNICÍPIOS BRASILEIROS COM PELO MENOS UMA BPM - Recorte por Região Possui ou não biblioteca pública municipal:



Graph 1: Brazilian municipalities with at least one public municipal library

Source: $1^{\text {st }}$ Census of Public Municipal Libraries

In light of this data, one can see that most of the public municipal libraries in the country are concentrated in the South and Southeast. The number of inhabitants per public libraries also varies significantly between regions - for example, the city of Curitiba, in the South, has approximately 26,000 inhabitants per public library while the city of Manaus, in the North, has 1,680,000 inhabitants per facility (CULTURA, 2009).

It is this state of affairs that inspires the creation of informal spaces that provide access to reading material and information - independent spaces, called community libraries. These differ from public municipal libraries, which are organized and maintained by the State.

The RBBC, initially established by a small group of people as a socio-cultural initiative, acquired the characteristics of a social movement in defense of libraries around the country. Like the new social movements described by authors such as Guindani 
(2009), Castells (1999), Downing (2002), Kauchakje (2005) and Assis (2006), this movement started to take shape via virtual networks, preserving their reformist nature, and using mobilization and integration strategies that are based on internet usage. These networks have fostered among the participants the sharing of skills, knowledge, objects and objectives for the short, medium and long term.

\section{THEORETICAL FOUNDATIONS FOR THE CONSTRUCTION OF THE RBBC}

It is important to clarify that in Brazil the community library is seen as an independent social project with no direct ties to government institutions and led by an organized group of individuals with the common purpose of increasing the access of community members to reading material and information, thereby promoting social emancipation (Machado, 2008). The community library is in essence a public space; however, in contrast to the state-sponsored "public library", it does not count on the constant work of librarians to organize and maintain its collection or to provide special services regarding the access of information to the community. It depends on the voluntary work of people who, in the majority of cases, have no formal training and have taken on the responsibility of providing the public with access to books and reading.

The fields of Librarianship and Information Science in Brazil have only recently begun to make room for studies on the topic of "community libraries." This means that the country still lacks organized information on the reality of these experiences. Hence, the establishment of a social network such as the RBBC constitutes a strategy to obtain information on this type of project. According to Marteleto (2001, p.73), "in informal spaces, the networks are formed based on the awareness of interests and/or values among the participants of a community" and the RBBC was formed precisely according to these principles.

The social network, in the words of Marteleto (2001, p.72), represents "a set of independent participants, bringing together ideas and resources around shared values and interests". For Lozares (1996, apud Gonzalez-Galvez and Rey-Martin, 2009, p.15), "social networks are like a fixed set of actors - individuals, groups, organizations, communities, societies - connected to one another according to a relationship or set of social relationships".

Sugahara and Vergueiro (2010, p.104) developed a study on the influence of social networks in the study of information flow and they point to the fact that the network has "on principle the participation of individuals and their colleagues as a basis for its definition and expansion." They also highlight the opportunity provided by these spaces for the "exchange and sharing of information and knowledge." According to the authors, in order to understand the information flows in social networks, one must investigate broadly, both the connections and interactions of the actors in a given social network as well as its interrelations with similar communities, for the members of these networks also have contact with other networks and social spaces. In this way, it is assumed that as the interactions between adjacent and non-adjacent actors change, so too does the information flow (Sugahara; Vergueiro, 2010, p.105). 
Social networks on the internet facilitate the possibility of establishing personal or professional relationships with individuals that do not know one another personally. This environment allows for the connections in the network to be strengthened in a situation in which the construction of the network itself is driven by the contribution of its own members, since "it is about sharing interests and needs by way of an open and dynamic system" (Gonzalez-Galvez and Rey-Martin, 2009, p.15).

In the case of virtual networks, Information and Communication Technologies (ICTs) should be used as a means and not as "an end in and of itself" (Carvalho et al., 2007). As its focus is on a specific community, there is no question that access to technology is a prerequisite for the network to have an impact in improving the conditions of the community libraries involved in the RBBC and, consequently, in the people involved in these projects.

Keeping in mind that we are dealing with communities that, for the most part, encompass disadvantaged groups, the application of the concepts proposed by Community Computing is essential. A number of authors (McLever, 2005; Carvalho et al., 2007) have put effort into researching and reflecting upon the importance of Community Computing in developing countries.

Community IT and Community Librarianship are interdisciplinary fields that promote participatory processes for the construction of social projects capable of introducing significant changes to specific communities regarding access to information and reading materials.

\section{METHODOLOGY}

Based on the principle that "the effective use of information and communication technologies depends on knowledge, skills, competencies and organizational and social support structures", for the construction of the RBBC, the members decided to adopt a platform that would be as easy to use as possible from the user's point of view.

Hence, the tool that was chosen was the online platform Ning[1] - which, at the time (November 2009), was free of charge. This platform is set up as a social interface in which each user can create his/her own social network and add other networks created by users that share similar interests. Since its creation, in 2005, Ning has stood out among other social networks because of its focus on subject matter, whereas other well-established networks, such as Facebook and Orkut, are focused on the user.

The next step was to establish the types of relationships and sharing of information, such as how to control and access the RBBC so as to:

- broaden the debate and discussions regarding community libraries in the country;

- promote the democratic participation of members;

- respect the diversity and cultural plurality of the various groups involved;

- value creative strategies;

- establish synergy between the actions, projects and people involved. 
Two members of the group were elected as web administrators; they were responsible for monitoring the activities of the network. In respect of democratic principles, the RBBC allows all participants to invite new members, define their own profiles, initiate a new debate in the forum page, include messages from blogs and communicate information about events related to the topic. Nevertheless, some areas were considered open to control on the part of the administrators, such as: opening user groups and adding photos and videos. The administrators also have the exclusive ability to send collective messages, such as bulletins and updates to highlights on the network, as well as guidelines for the use of certain resources. The interventions of the administrators are conducted with the aim of ensuring the quality of the information that is circulated on the network and keeping the focus on the interest topics of the group the library as a space that provides reading material and information in the country.

The RBBC is monitored by Google Analytics [2] , which allows for the verification of data regarding the number of visits per day and the average time spent on the website, as well as controlling crucial data like the statistics on the network's national penetration, with the geographical location of its members. Other technical data provided facilitates in defining new services that could be used on the network.

It is important to clarify that Ning has since undergone a change in business direction and has turned into a tool that requires exclusive membership. Hence, the RBBC has managed to secure sponsorship from a collection management software company[3] in order to ensure its continuity.

\section{CURRENT SCENARIO OF THE RBBC}

Considering the fact that the experience of the RBBC is still very recent, it has not been possible to develop a detailed analysis of the network. The project is currently in the data collection phase, after which the systematized information can be assessed for the purpose of identifying the different relationships that were established in the new environment. However, we can already present an overview of the RBBC's current scenario, based on access data such as the network's geographical scope and the profile of the participants, as well as a snapshot of the most popular content.

Although the scope of the RBBC is national, based on the data collected from Google Analytics, we could see that people from all over the world accessed the network. Of the 11,647 visits that were made to the network between the period of 26 November 2009 and 26 September 2010 (that is, in the first 10 months of its existence), the absolute majority were made from Brazil (11,262 visits), with the remaining 385 visits originating in 40 countries located in Africa, the Americas, Asia, Europe and Oceania[4].

The 11,262 visits from the national territory originated in over 205 unique Brazilian cities[5]. The majority of the visits to the RBBC were concentrated in the Southeast of the country, followed by the Northeast, South, Center-West and North. Graph 2, below, summarizes the basic data regarding the main 15 cities that brought Brazilian visitors to the RBBC: 


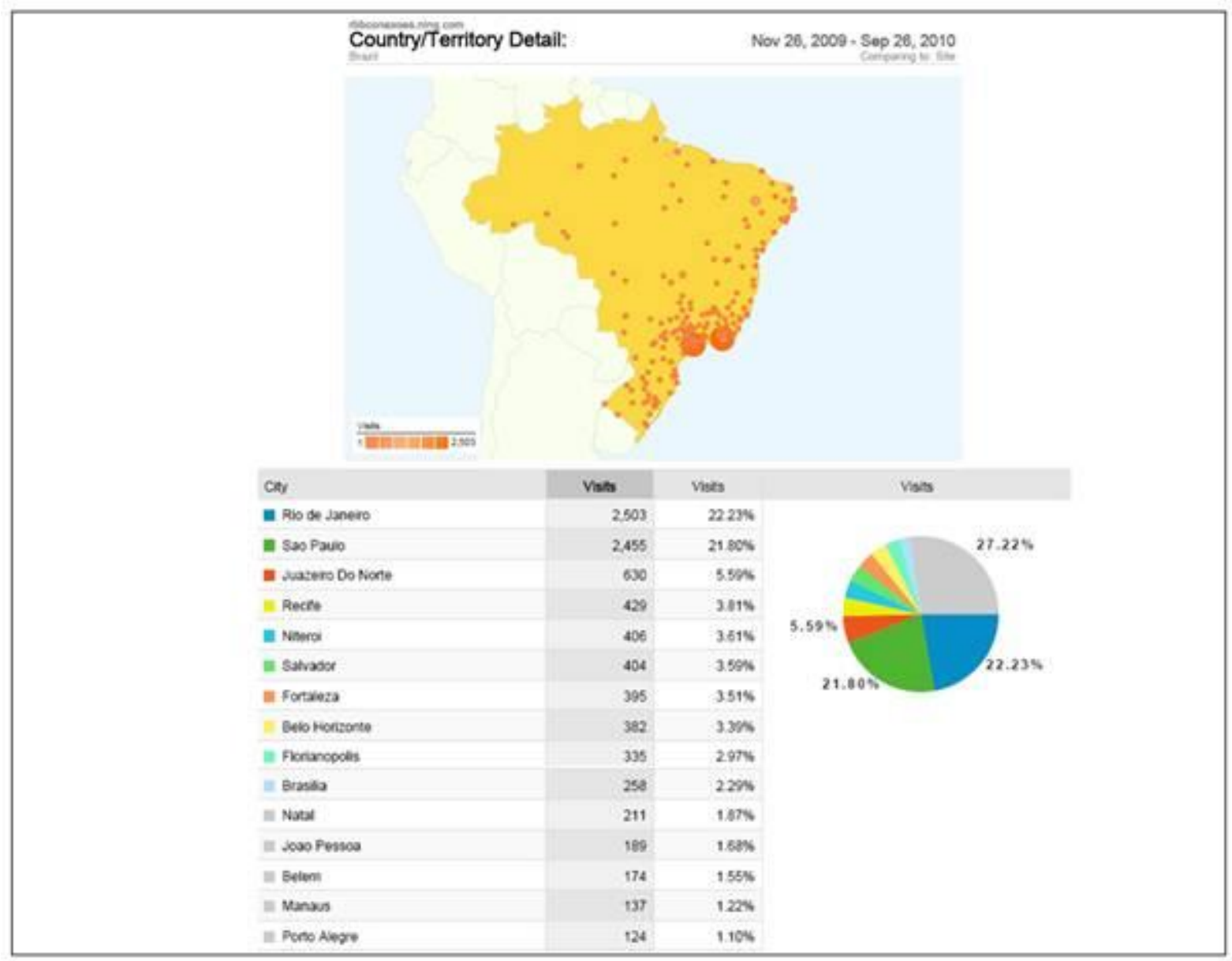

Graph 2: Main cities, by visits

Source: Google Analytics

It is important to explain that the Southeast is the region with the most developed internet infrastructure in Brazil. According to the Brazilian Institute of Geography and Statistics (IBGE, 2009), in the last 3 years, there was a $75.3 \%$ increase in internet usage in the country; however, regional inequalities are reflected in the number and type $e_{[6]}$ of access.

During the 10 months of RBBC activity that were analyzed, we observed continuous use of the network, with almost 40 daily visits. As shown in Graph 3, there was a higher access rate in 2010 and we hope the rising use of the RBBC constitutes a long term trend.

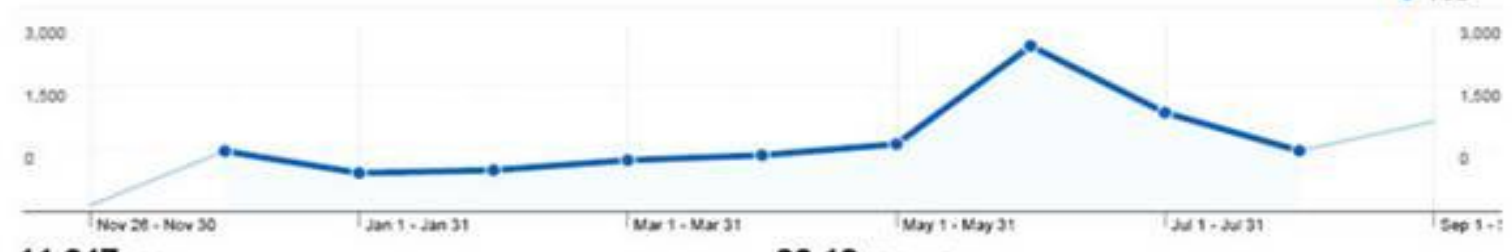


The average time spent on the network was 4.01 minutes. A drop in this variable was observed in 2010 , but it now appears to be rising to previously recorded levels. The trend can be seen in Graph 4.

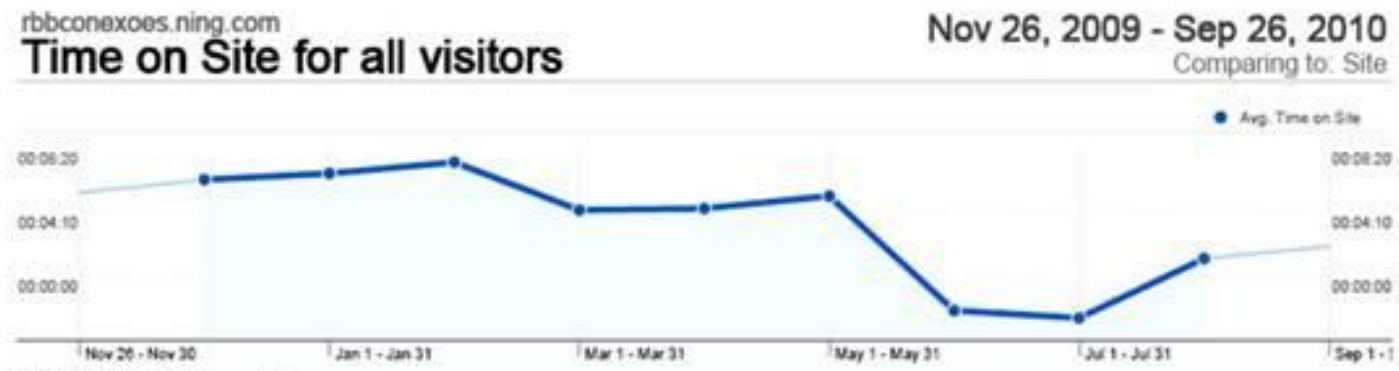

00:04:01 Avg. Time on Ste

Graph 4: Average time per visit

Source: Google Analytics

At present, the network counts on an online community of almost 600

participants/actors. Through the mandatory information at registration and usage, it has been possible to identify the profile of the actors, gearing them towards specific content on the network, people with close geographical locations to the new members, as well as information to help them in their activities, which are not necessarily found on the RBBC itself. Hence, even in these early stages of the project, the full potential of the social network as a helpful tool is already noticed by the new participants.

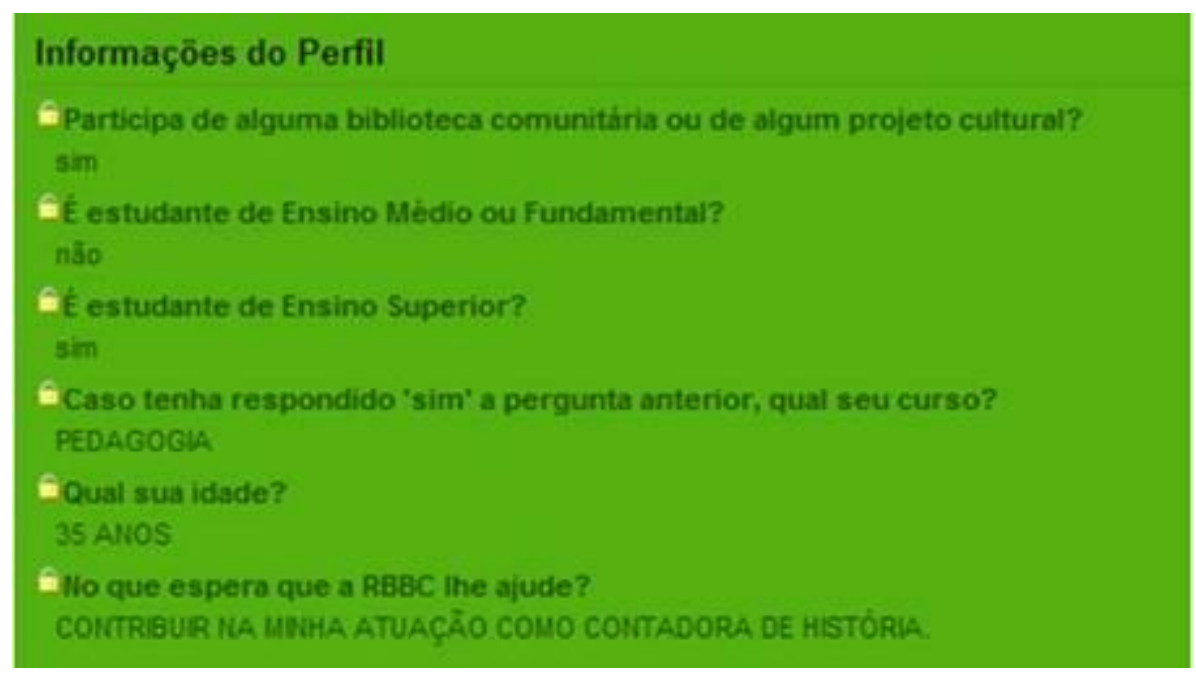

Figure 2: Initial identification of the profile of new members of the RBBC Source: http://rbbconexoes.ning.com [ retrieved 30/10/2010]

One way to track the exchange of information and content that has been circulating on the network is to analyze the Forums page, where many types of collection exchanges occur, with a total of 7,500 accesses in the analyzed period. Below is a list of the 10 most popular threads, or the topics that were most studied, in the RBBC: 


\begin{tabular}{|l|c|c|}
\hline \multicolumn{1}{|c|}{ Title } & Opening Date & $\begin{array}{c}\text { Number of } \\
\text { contributions }\end{array}$ \\
\hline Introducing the Members & $15 / 11$ & 84 \\
\hline Meeting of Community Libraries & $19 / 11$ & 58 \\
\hline Public Policy for Libraries & $13 / 12$ & 25 \\
\hline Academic studies on Community Libraries & $22 / 11$ & 16 \\
\hline Arca das Letras - Rural Libraries & $29 / 11$ & 15 \\
\hline Sustainability & $26 / 11$ & 14 \\
\hline Comments and Recommended Books, Videos, etc. & $26 / 01$ & 13 \\
\hline Launch of the Book Collection Campaign & $23 / 11$ & 12 \\
\hline Personal accounts and experiences & $22 / 11$ & 10 \\
\hline Appeal for Books & $26 / 11$ & 09 \\
\hline Vaga Lume Community Library & $01 / 12$ & 09 \\
\hline List of Community Libraries & $01 / 12$ & 09 \\
\hline
\end{tabular}

Table 1: List of the 10 most popular forums in the RBBC Source: http://rbbconexoes.ning.com [retrieved on 30/10/2010]

The network currently lists 60 open forums for debate, the most popular of which is entitled "Introducing the members," in which each participant may introduce himself upon entering the network. This is followed by the forum "Meeting of Community Libraries," a space reserved for organizing an actual physical meeting for the members in the network, and then by the "Public Policy for Libraries" forum, in which participants can discuss the need for the creation of guidelines and funding for public, community and school libraries in the country. Another forum that has brought together interesting information concerns the topic of academic studies on community libraries; the space has become a reference point for new research in the field.

The Personal Pages of the members are another space worth highlighting. It is from the personal homepage that conversations between the different actors in the RBBC occur, and this area had approximately 5,550 accesses. Also noteworthy are the areas with audiovisual content - "Videos" and "Photos" - with 2,400 accesses. At present, the RBBC has 40 videos and 700 photos in its collection, all of which can be accessed by any of the participants in the network. Finally, the "Events" area, where participants can spread the word regarding activities that take place in their Community Libraries, has been accessed approximately 1,300 times.

\section{REFLECTIONS ON THE RBBC}

It is important to remember that the effects of any experience cannot be identified at the beginning of the process, but rather throughout the length of its duration. Existing methodologies suggest the need to monitor an action for a given length of time and only then to evaluate its results and identify its effects. At the moment, we can only point to the first tendencies identified regarding the use of the RBBC, its appropriation and the involvement of its participants.

Given the 586 members that the RBBC has incorporated in the short time span of 10 months, it is clear that the idea of bringing together people interested in the topic "community libraries" was well received. This confirms the initial hypothesis that there were few open spaces for debate regarding this topic. 
The area reserved for Forums is understood as one that will allow the development of discussions and debates based on topics proposed by the participants, thereby generating a real and effective exchange of information. After analyzing this area, we could attest to the existence of an excess of topics open for debate - in some cases, the topics repeated themselves. Nevertheless, it is important to emphasize that, despite being a free and open space, the members did not lose their focus on the topic. All of the contributions were made to express concerns, present proposals, report experiences, present solutions to certain problems, answer questions asked by other members of the network and spread the word regarding actions that met with success in the community or media at large.

There is a feeling that the Forum section, as well as the section reserved for Photos and Videos, demand a certain level of control; alterations should be made in order to improve the discussion process. The idea is that if a participant proposes a topic that is already being discussed in any of the other open forums, the web administrator can send the person a message explaining that he or she should enter the open forum and post his or her message there. In this way, the person will be put in the right direction and integrated into the appropriate interest group. Such a mechanism could also streamline and enrich the debates that are currently very fragmented.

It is clear that sending photos and/or videos of the libraries and the projects and actions that the members undertake is much preferred by participants. There is no question that the ease with which one attaches an image or uploads a short film is greater than that of elaborating a text or answering a question proposed in a debate. Hence, it makes sense that these were the tasks that were most incorporated by the participants. In a collaborative fashion, the RBBC participants are putting together a collection of photos and images, all of which are related to the topic, and this has turned the space into yet another source of material for researchers and laypeople interested in the matter.

In addition to the debates in the Forum section, contact between leaders of community libraries, students of Library Sciences, librarians, researchers and interested laypeople is frequent. In some cases, it is by way of individual messages that the participants prefer to share ideas and information regarding projects and processes that involve their personal experiences. In other words, the RBBC has become a medium for the establishment of ties between projects, institutions and people as well as between academia and society.

It is important to emphasize that the administrators have thus far made very few interventions. Some of the forums were reorganized so as to give continuity to the discussions and only two people had their access denied because they were using the network to send spam to the other members. All of the uploaded videos were screened and allowed on the network, since they were in keeping with the topic. As for the photos, only four failed to be accepted, as they were not directly or indirectly related to the group's topic of interest.

As a means to encourage debate and inform users of the tools available on the network, a newsletter was developed and sent to all members. The newsletter 
highlights ongoing discussions in the forums, comments on recently uploaded videos and photos, as well as tips to improve the performance of the network's members.

The group has also put serious effort into organizing a physical meeting at some point in the future. The idea is to bring the discussions from the network to the physical meeting and then continue the debates at a distance, on the network, as a cyclical, ongoing process. The aim is that the network will feed the physical meeting and vice versa. However, a physical meeting requires the formation of partnerships, which require a complex set of exchanges and should be established prudently and at the appropriate time. It is our hope that these support mechanisms not only help to make the network a concrete reality, but also enrich the internal relationships, thereby ensuring the project's ongoing continuity, strength and enhancement.

\section{FINAL CONSIDERATIONS}

With the creation of the RBBC, yet another opportunity has been established to effectively make use of Information and Communication Technologies (ICTs) by an offline community - maintainers of Community Libraries in Brazil. In this case, ICTs were used in a deliberate manner to serve as a communication medium for groups of people that currently work separate from one another with the aim of enhancing the exchange of information and creating new knowledge.

The Rede Brasil de Bibliotecas Comunitárias, or RBBC, an open and dynamic social network, has allowed people involved in the project of creating reading spaces around the nation to share common interest and needs. One could say it is a potential environment for social integration. By way of the RBBC, associations between academic studies, institutionalized practices and independent and creative actions are triggered by average citizens, who have boldly taken on the challenge of dealing with the lack of access to information and reading material in this country.

\section{REFERENCES}

ASSIS, É. G. de. (2006). Táticas lúdico-midiáticas no ativismo político contemporâneo. Unpublished dissertation, Universidade do Vale do Rio dos Sinos, São Leopoldo. Retrieved May, 5, 2010, from http://pontomidia.com.br/erico/rodape/ericoassisdissertacao.pdf

BRASIL. MINISTÉRIO DA CULTURA; FUNDAÇÃO GETÚLIO VARGAS (2010). Censo das Bibliotecas Públicas Municipais, 2010. Brasília: MinC.

CARVALHO, A. R. et al. (2007) Apenas acesso participativo e universal ao conhecimento. CONGRESSO da SBC. Anais do Congresso da Sociedade Brasileira de Computação, 27, 2247-2261. Retrieved May, 5, 2010, from www.sbc.org.br/bibliotecadigital/download.php?paper=681

CASTELLS, M. (1999). A sociedade em rede. São Paulo: Paz e Terra.

CULTURA em números: anuário de estatísticas culturais 2009. (2009). Brasília: Minc. 
DOWNING, J. D. H. (2002). Mídia radical: rebeldia nas comunicações e movimentos sociais. São Paulo: Senac. Retrieved May, 5, 2010, from

http://books.google.com.br/books?id=oQUMpK1fcB4C\&printsec=frontcover\&dq=Rebel dia+nas+comunica\%C3\%A7\%C3\%B5es+e+movimentos+sociais\&ei $=36 \mathrm{eS}$ P3ClvEy AT3x6TgAw\&cd=1\#v=onepage \&q=\&f=false

GIDDENS, A. (1996). Para além da esquerda e da direita. São Paulo: UNESP.

GONZÁLEZ GÁLVEZ, P.; REY MARTíN, C. (2009). Redes sociales como fuente de capital social: uma reflexón sobre la utilidad de los vínculos débiles. RISTI: Revista Ibérica de Sistemas e Tecnologias de Informação, 3, 13-24. Retrieved May, 5, 2010, from http://www.aisti.eu/index.php?option=com content\&task=view\&id=59\&ltemid=63

GUINDANI, J. F. (2009, 2 junho). Alienação ou Libertação? Quem tem medo da internet? Observatório da Imprensa, E-Notícias. Retrieved May, 5, 2010, from http://www.observatoriodaimprensa.com.br/artigos.asp?cod=540ENO001

IBGE. (2009). Acesso à Internet e posse de telefone movel celular para uso pessoal. Brasília: IBGE. Retrieved May, 5, 2010, from

http://www.ibge.gov.br/home/presidencia/noticias/noticia visualiza.php?id noticia=151 $\underline{7 \& \text { id } \text { pagina }=1}$

KAUCHAKJE, S. (2005). Alternatives pour recomposer les liens sociaux et la civilité dans les rapports sociétaires au Brésil. Revista Res Socialis, Fribourg Suisse, 24, 165178.

MACHADO, E. C. (2008). Bibliotecas comunitárias como prática social no Brasil. Unpublished doctoral dissertation, Escola de Comunicação e Artes, Universidade de São Paulo.

MARTELETO, R. M. (2001). Análise de redes sociais: aplicação nos estudos de transferência da informação. Ciência da Informação, Brasília, 30(1), 71-81. Retrieved May, 5, 2010, from http://www.scielo.br/pdf/ci/v30n1/a09v30n1.pdf

MCLEVER Jr., W. (2005). Uma informática comunitária para a sociedade da informação. In MARQUES DE MELO, J. SATHLER, L. Direitos à comunicação na Sociedade da Informação (pp. 64-102). São Bernardo do Campo: UNESP. Retrieved May, 5, 2010, from

http://www.lucianosathler.pro.br/site/images/conteudo/livros/direito a comunicacao/65 102 direitos a comunicacao informatica comunitaria mciver.pdf

PRADO, G. M. (2009). Biblioteca comunitária: território da memória, informação e conhecimento In: BRAGA, G. M.; PINHEIRO, L. V. R. (Org.). Desafios do impresso ao digital: questões contemporâneas de informação e conhecimento (pp. 365-386). Brasília : IBICT.

SUGAHARA, C. R.; VERGUEIRO, W. (2010). Aspectos conceituais e metodológicos de redes sociais e sua influência no estudo de fluxos de informação. Revista Digital de 
Biblioteconomia e Ciência da Informação, Campinas, 7(2),102-117. Retrieved May, 5, 2010, from http://www.sbu.unicamp.br/seer/ojs/viewarticle.php?id=237

[1] Web address: http://www.ning.com/

[2] Web address: http://www.googleanalytics.com/

[3] Web address: http://www.alexandria.com.br

[4] Countries ranked in order of number of visits: Portugal, China, USA, Argentina, Angola, Pakistan, Chile, Uruguay, Germany, Colombia, Japan, France, Italy, Belgium, United Kingdom, São Tomé and Príncipe, Spain, Senegal, Cape Verde, Denmark, Cuba, the Netherlands and Russia.

[5] There are approximately 5.565 cities in Brazil. The exact number of cities from which the website was accessed cannot be determined, since Google Analytics was unable to recognize the origins of 49 visits.

[6] At home or in public centers. 